Chirurgia (2019) 114: 83-88

No. 1, January - February

Copyright $@$ Celsius

http://dx.doi.org/10.21614/chirurgia.114.1.83

\title{
Can Neutrophil to Lymphocyte Ratio Be a Predictor Tool for The Non-Sentinel Lymph Node Metastasis in Breast Cancer?
}

\author{
Atak Ibrahim ${ }^{1}$, Yegen Fatih Serkan' ${ }^{1}$, Atak Tuba ${ }^{2}$, Bagcivan Erol ${ }^{1}$, Polat Lütfi ${ }^{1}$ \\ ${ }^{1}$ Ali Osman Sönmez Oncology Hospital, Department of General Surgery, Bursa, Turkey \\ ${ }^{2}$ Çekirge State Hospital, Department of General Surgery, Bursa, Turkey
}

Corresponding author: Ibrahim Atak, MD

Prof. Dr. Orhan Kamıș street, no. 3

Osmangazi, Bursa-Turkey

Tel: +902242238200

Fax: +902242251051

E-mail: driatak@yahoo.com
Received: 15.12 .2017 Accepted: 14.03 .2018

\section{Rezumat}

Poate contribui raportul neutrofile/limfocite la diagnosticarea preliminară a metastazelor nodului limfatic non-santinela în cancerul de sân?

Scop: Investigarea unei potențiale relații între raportul neutrofile /limfocite (NLR) şi procentul metastazării nodurilor limfatice nonsantinelă (NSLN) în cancerul mamar timpuriu.

Metode: Datele clinice ale pacienților cu cancer mamar invaziv în stadiu incipient clinic (cT1-3,N0), care au beneficiat de biopsie ghidată cu substanță de contrast şi limfoscintigrafic între Aprilie 2015 şi Ianuarie 2017, au fost prelucrate retrospectiv. Valoarea NLR la întregul grup de pacienți, indiferent de statusul NSLN, a fost înregistrată pre-tratament.

Rezultate: Un număr total de 178 de pacienți cu vârsta medie de $51,65 \pm 10,93$ ani au fost incluşi în studiu. NLR a fost statistic semnificativ la pacienții cu NSLN invadat $(p=0.011)$. Invazia limfovasculară şi extensia extracapsulară la nivelul nodului limfatic santinelă (SLN) au intervenit mai frecvent la pacienții NSLN invadat $(p<0.05)$. Riscul de metastazare în nodurile limfatice (N1) la pacienții cu invazie limfovasculară a fost semnificativ mai ridicat (OR 3,733 (95\% CI: 1,05-13,24). Riscul de metastazare la nivelul NSLN a fost de circa 10 ori mai ridicat la pacienții cu invazie capsulară comparativ cu cei fără invazie capsulară (OR 10,267; 95\% CI: 2,63-40,12).

Concluzii: İnvazia limfovasculară, extensia extracapsulară şi NLR reprezintă parametrii predictivi ai pozitivitătii NSLN. Calcularea preoperatorie a NLR reprezintă un instrument predictiv util în ceea ce priveşte estimarea riscului de invazie malignă a NSLN. 
Cuvinte cheie: cancerul mamar, raportul neutrofile/limfocite, metastaze în nodurile limfatice nonsantinelă, metastaze în nodul limfatic santinelă

\section{Abstract}

Background: To investigate the relationship between neutrophil to lymphocyte ratio (NLR) and non-sentinel lymph node (SLN) metastasis in early stages of breast cancer

Methods: Records of patients with clinically early stage (cT1-T3, N0) invasive breast cancer who underwent SLN biopsy in combination with blue dye and lymphoscintigraphy between April 2015 and January 2017 were noted retrospectively. Pre-treatment NLR of the patients with and without non-SLN metastasis were compared.

Results: A total of 178 patients with a mean age of 51,65 10,93 years were included. NLR was statistically significant in the non-SLN positive patients $(\mathrm{p}=0.011)$. Lymphovascular invasion and extracapsular extension of SLN were more common in the non-SLN positive group (all $p<0.05$ ). The ODDS value was found to be 3,733 (95\% CI: 1,05-13,24) and the risk of metastasis in those with lymphovascular invasion was 3.73 fold. The ODDS value was found to be 10,267 (95\% CI: 2,6340,12 ) and the risk of metastasis was 10,267 times greater in those with capsule spread.

Conclusion: Lymphovascular invasion, extracapsular extension and NLR are the predictive parameters of non-SLN positivity. Pre-surgical NLR is a useful diagnostic tool for predicting non-SLN metastasis.

Key words: breast cancer, neutrophil to lymphocyte ratio, non-sentinel lymph node, sentinel lymph node metastasis

\section{Introduction}

Axillary lymph node dissection is performed in invasive breast cancer patients who had positivity of sentinel lymph node biopsy (SLNB) in routine practice. Nonetheless, since $40 \%$ to $70 \%$ of patients have metastatic axillary lymph nodes only in the sentinel lymph node (SLN), the identification of factors predicting axillary non-sentinel node involvement may reduce unnecessary axillary dissection and reduce morbidity (1-3). On the other hand, neutrophil to lymphocyte ratio (NLR), a marker of systemic inflammation, has been studied and reported to be predictive of some types of breast cancer $(4,5)$. However, to the best of our knowledge, there is only one study has been conducted on the use of the NLR in the determination of the non-SLN metastasis (6). Therefore, the objective of this study was to investigate the relationship between NLR and non-SLN metastasis in early stages of breast cancer.

\section{Methods}

\section{Study design and participants}

This study was conducted retrospectively. Records of patients with clinically early stage (cT1-T3, N0) invasive breast cancer who underwent SLNB with blue dye or in combination with blue dye and lymphoscintigraphy between April 2015 and January 2017 were noted.

Patients who had any of the following criteria were excluded; cT3-T4 carcinoma, distant metastasis at initial diagnosis, systemic neoadjuvant chemoradiotherapy, having active infection, steroid usage. Clinical and demographical features of the patients including age, tumor size, histologic grade, number of positive and negative lymph nodes, number of positive and negative Non-SLN, ER, PR status, HER2 status, LVI presence, Ki67 index and preoperative NLR. 


\section{Sentinel lymph node biopsy with combined method}

Each patient underwent planar lymphocytography with Tc99m-Nanocolloid (SENTI-SCINTKIT) $2-6$ hours before the operation in the department of nuclear medicine. A total of $200 \mathrm{MBq} / \mathrm{ml}$ periaerolar was administered subdermally with four injections (50 Mbq/0.25 $\mathrm{ml}$ in each injector). Dynamic static imaging was performed following injections. The skin projection of the SLN was marked. $5 \mathrm{~mL}$ of $1 \%$ methylene blue was injected-subaerosol and subdermal- immediately after general anesthesia before the onset of the disease. Following the injection, massaging from the injected area to axillary region was applied to accelerate the lymphatic flow. A transverse skin incision was made $1 \mathrm{~cm}$ below the armpit hairline 7-10 minutes after the end of the injection procedure. Painted canal and lymph nodes were determined by passing through the clavipectoral fascia. The lymph nodes were ex vivo counted by gamma probe after the procedure and the findings were noted. The axillar region was scanned with a gamma probe. More than $10 \%$ of the activity value in the highest counted lymph node was subtracted from the lymph node counts. Removed lymph nodes were sent to the patho-logy clinic for frozen examination and the planned operation was performed. Level 1 and Level 2 axillary lymph node dissection were performed in patients with SLNB positive.

\section{Neutrophil to Lymphocyte Ratio Evaluation}

Blood count data preoperatively were collected retrospectively. NLR was defined as the absolute neutrophil count divided by the absolute lymphocyte count.

\section{Statistical analysis}

Statistical analysis was performed with the NCSS (Number Cruncher Statistical System) 2007 Statistical Software (Utah, USA) program. Mann Whitney U test was used for the comparison of descriptive statistical methods (mean, standard deviation, median, frequency, ratio) as well as non-normal distribution of parameters between groups when study data were evaluated. For cut-off point detection for NLR, ROC analysis and diagnostic screening tests were used. Pearson's Chi-square test, Fisher's Exact test and Fisher-Freeman Halton test were used for comparison of qualitative data. The results were evaluated in a confidence interval of $95 \%$ and a significance level of $\mathrm{p}<0.05$.

\section{Results}

A total of 178 patients with a mean age of $51,65 \pm 10,93$ years were included. Clinical features of the patients are summarized in Table 1.

Of the patients, 47 (26.4\%) had SLN metastasis. In the group of patients with SLN metastasis, 19 patients (40.4\%) had an additional non-SLN metastasis. Tumor size, NLR, and SLN size of the patients with and without nonSLN metastasis are shown in Table 2. NLR was

Table 1. Clinical characteristics of the cases

\begin{tabular}{|c|c|c|c|}
\hline & Mean士SD & Min-Max & \\
\hline Age (year) & $51.65 \pm 10.93$ & $32-80$ & \\
\hline \multirow[t]{2}{*}{ Tumor Size (mm) } & $21.87 \pm 8.47$ & $10-45$ & \\
\hline & $\mathrm{N}$ & $\%$ & \\
\hline \multirow[t]{2}{*}{ T Grade } & $\mathrm{T} 1$ & 84 & 47.2 \\
\hline & $\mathrm{T} 2$ & 94 & 52.8 \\
\hline \multirow[t]{4}{*}{ Tumor location } & Lower medial & 25 & 14.0 \\
\hline & Lower lateral & 37 & 20.8 \\
\hline & Üpper medial & 39 & 21.9 \\
\hline & Upper lateral & 77 & 43.3 \\
\hline \multirow[t]{2}{*}{ SLNB Technique } & Blue dye & 77 & 43.3 \\
\hline & Combined Method & 101 & 56.7 \\
\hline \multirow[t]{6}{*}{ SLN Count } & 0 & 4 & 2.2 \\
\hline & 1 & 33 & 18.5 \\
\hline & 2 & 85 & 47.7 \\
\hline & 3 & 38 & 21.3 \\
\hline & 4 & 14 & 7.9 \\
\hline & 5 & 4 & 2.2 \\
\hline \multirow[t]{3}{*}{ Histologic Grade } & Grade 1 & 30 & 16.9 \\
\hline & Grade 2 & 92 & 51.7 \\
\hline & Grade 3 & 56 & 31.5 \\
\hline \multicolumn{4}{|l|}{ Postoperative } \\
\hline \multirow[t]{6}{*}{ Diagnosis } & Invasive ductal Ca & 157 & 88.2 \\
\hline & Invasive lobular $\mathrm{Ca}$ & 15 & 8.4 \\
\hline & İnvasive apocrine Ca & 1 & 0.6 \\
\hline & Medullar $\mathrm{Ca}$ & 2 & 1.1 \\
\hline & Metaplastic Ca & 2 & 1.1 \\
\hline & Mucinous $\mathrm{Ca}$ & 1 & 0.6 \\
\hline
\end{tabular}


statistically significant in the non-SLN positive patients $(p=0.011)$. Comparison of the clinical characteristics of the tumor according to the non-SLN metastasis is shown in Table 3. Lymphovascular invasion (LVI) and extracapsular extension of SLN were more common in the non-SLN positive group (all $\mathrm{p}<0.05$ ). The ODDS value was found to be 3,733 (95\% CI: $1,05-13,24)$ and the risk of metastasis in those with LVI was 3.73 fold. The ODDS value was found to be 10,267 (95\% CI: 2,63-40,12) and the risk of metastasis was 10,267 times greater in those with capsule spread.

ROC curve showing the sensitivity and specificity of NLR is demonstrated in Fig. 1. The NLR's ROC curve was 0.7 (95\% CI 0.50.8). Sensitivity to non-SLN metastasis positivity in patients with NLR> 1.80 was $68.42 \%$; specificity $71.43 \%$; positive predictive value of $61.9 \%$ and negative predictive value of $76.92 \%$. In the obtained ROC curve, the underlying area was $71.9 \%$ and the standard error was $7.8 \%$.

Factors affecting the non-SLN metastasis LVI, Positive SLN extracapsular extension, and NLR- were evaluated by Enter Logistic regression analysis.The model was meaningful and the explanatory coefficient of the model (76.6\%) was acceptable. The effect of positive SLN extracapsular extension was statistically significant $(p<0,01)$. The ODDS ratio of the effect on non-SLN metastases was found to be 7,309 (95\% CI: 1.64-32.55) times higher. The ODDS value of the effect of the level of LVI was

Table 2. Comparison of the age, tumor size, neutrophil to lymphocyte ratio, and size of the sentinel lymp node according to the non-sentinel lymph node metastasis

\begin{tabular}{llccc}
\hline & & $\begin{array}{c}\text { Non-SLN metastasis }(-) \\
(\mathbf{N}=\mathbf{2 8})\end{array}$ & $\begin{array}{c}\text { Non-SLN metastasis (+) } \\
(\mathbf{N}=\mathbf{1 9})\end{array}$ & $\boldsymbol{P}$ \\
\hline Age (year) & mean \pm SD & $53.79 \pm 11.56$ & $48.37 \pm 9.75$ & 0.123 \\
& Min/Max (Median) & $36-78(54.5)$ & $32-66(50)$ & \\
Size of the tumor (mm) & mean \pm SD & $22.18 \pm 9.51$ & $21.42 \pm 6.87$ & 0.939 \\
& Min/Max (Median) & $10-45(20)$ & $10-35(20)$ & \\
\hline NLR & mean \pm SD & $1.68 \pm 0.69$ & $2.28 \pm 0.79$ & $0.011^{*}$ \\
& Min/Max (Median) & $1-3.7(1.6)$ & $1.2-3.7(2.3)$ & \\
\hline Size of the SLN & mean \pm SD & $16.04 \pm 5.9$ & $15.16 \pm 4.74$ & 0.807 \\
& Min/Max (Median) & $10-35(15)$ & $8-25(15)$ & \\
\hline
\end{tabular}

Table 3. Comparison of the cases according to the non-sentinel lymph node metastasis

\begin{tabular}{|c|c|c|c|c|}
\hline & & $\begin{array}{l}\text { Non-SLN metastasis }(-) \\
(\mathrm{N}=28)\end{array}$ & $\begin{array}{l}\text { Non SLN metastasis }(+) \\
\qquad(N=19)\end{array}$ & $P$ \\
\hline \multirow[t]{2}{*}{ Grade; n (\%) } & T1 & $7(25)$ & $4(21.1)$ & ${ }^{\mathrm{a}} 1.000$ \\
\hline & $\mathrm{T} 2$ & $21(75)$ & $15(78.9)$ & \\
\hline \multirow[t]{3}{*}{ Histologic Grade; n (\%) } & 1 & $3(10.7)$ & $1(5.3)$ & 0.576 \\
\hline & 2 & $16(57.1)$ & $14(73.7)$ & \\
\hline & 3 & $9(32.1)$ & $4(21.1)$ & \\
\hline \multirow[t]{2}{*}{ LVl; n (\%) } & No & $16(57.1)$ & $5(26.3)$ & $0.037^{\star}$ \\
\hline & Yes & $12(42.9)$ & $14(73.7)$ & \\
\hline \multirow[t]{2}{*}{$\mathrm{ER} ; \mathrm{n}(\%)$} & Negative & $2(7.1)$ & $5(26.3)$ & ${ }^{\mathrm{a}} 0.102$ \\
\hline & Positive & $26(92.9)$ & $14(73.7)$ & \\
\hline \multirow[t]{2}{*}{ PR; n (\%) } & Negative & $4(14.3)$ & $4(21.1)$ & ${ }^{\mathrm{a}} 0.697$ \\
\hline & Positive & $24(85.7)$ & $15(78.9)$ & \\
\hline \multirow[t]{2}{*}{ CERBB2; n (\%) } & Negative & $16(57.1)$ & $12(63.2)$ & ${ }^{a} 0.767$ \\
\hline & Positive & $12(42.9)$ & $7(36.8)$ & \\
\hline \multirow[t]{2}{*}{ Kİ67 Index group; n (\%) } & $<14$ & $8(28.6)$ & $8(42.1)$ & 0.337 \\
\hline & $\geq 14$ & $20(71.4)$ & $11(57.9)$ & \\
\hline \multirow[t]{2}{*}{ Positive SLN extracapsular extension; n (\%) } & No & $22(78.6)$ & $5(26.3)$ & $0.001 * *$ \\
\hline & Yes & $6(21.4)$ & $14(73.7)$ & \\
\hline
\end{tabular}




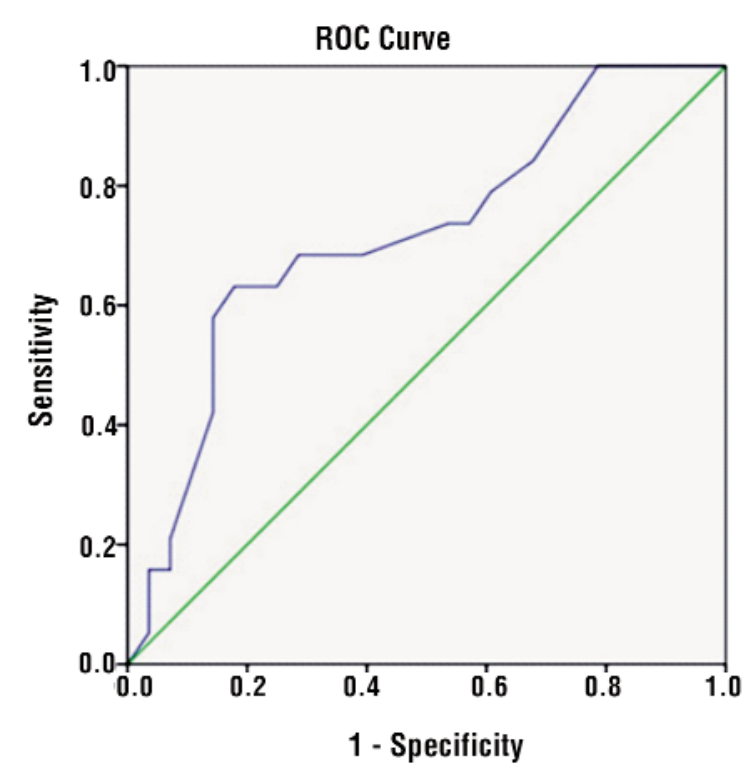

Figure 1. ROC curve. ROC curve showing the sensitivity and specificity of neutrophil to lymphocyte ratio

4,092 (95\% CI: $0,876-19,118)$ and the ODDS ratio of the effect of the NLR level of 1,80 and higher was found to be 4,076 (95\% CI: $0,896^{-}$ 18,554) (Table 4).

\section{Discussion}

In this study, we aimed to explore whether the NLR is a predictive tool for non-SLN metastasis. According to our results, we have two main findings. First, NLR was statistically significant in the non-SLN positive patients. Aside from the NLR, LVI and extracapsular extension of SLN were found to be predictive for non-SLN metastasis.

The NLR, obtained by the number of neutrophils and lymphocytes, is used as a simple tool evaluating systemic inflammation. Many studies have shown that NLR is correlated with the prognosis in breast, colorectal, gastric, pancreas, hepatocellular, and renal cancers. Neutrophils are known to promote tumor cell proliferation, angiogenesis, and distant metastasis as well as lymphocytes play a central role in the immune response to tumor cells. From this point of view, NLR is predicted to be associated with prognosis $(4,7-9)$.

As regards the association between NLR and breast cancer, there are some studies in the literature. In a large cohort study of 442 patients with breast cancer, it was shown that patients with high NLR $(\geq 2.5)$ had statistically significantly lower survival times than those with low NLR (<2.5) (4). Koh et al. (9) have shown that high NLR $(>4)$ is associated with larger tumor, high grade, and distant metastasis. There is only one report whether the NLR is predictive of non-SLN metastasis.

Laohawiriyakamol et al. (6) determined NLR, LVI, and SLN as predictive factors in nonSLN metastasis in 214 cases. They reported LVI (OR 8.4, 95\%CI 2.3-31.3, $\mathrm{p}=0.002$ ), macrometas $^{-}$ tasis (OR 6.6, 95\%CI 1.8-24.7, $\mathrm{p}=0.005$ ), and NLR（OR 2.3, 95\%CI 1.1-4.8, p=0.033） as predictive factors of non-SLN metastasis with statistical significance. NLR with an optimal cut-off of 2.6 has given a sensitivity of $62 \%$, a specificity of $83.8 \%$, a positive predictive value of $77.3 \%$ and a negative predictive value of $70.5 \%$. They highlighted that NLR is a useful diagnostic tool for predicting additional non-SLN metastasis (6). Our results showed similar results with the study done by Laohawiriyakamol et al. Moreover, although having SLN metastasis, 28 patients (40.4\%) had negative non-SLN biopsy.

There are several studies taking into account the clinicopathologic factors predicting non-SLN metastasis (10-12). LVI and number of positive and negative SLNs and their sizes are predic-

Table 4. Logistic regression analysis of the factors affecting Non-SLN metastasis

\begin{tabular}{lcccc}
\hline & p & ODDS & \multicolumn{2}{c}{ \%95 CI } \\
\hline Lymphovascular invasion & & & Lower & Upper \\
\hline Positive SLN extracapsular extension & 0,073 & 4,092 & 0,876 & 19,118 \\
\hline NLR $\geq 1,80$ & $0,009^{* *}$ & 7,309 & 1,641 & 32,552 \\
\hline
\end{tabular}


tive factors for non-SLN metastasis (11). Koca et al. (12) determined presence of LVI, tumor size, presence of extranodal spread in SLN, and the presence of metastatic SLN as independent predictors of non-SLN metastasis. Tumor size, SLN count, number of positive SLN, extranodal spread and histology have been identified as factors that play a role in determining the possibility of additional axillary metastases in the MD Anderson nomogram (13). Likewise, in our study LVI and extracapsular invasion were found to be the independent risk factors.We have some important drawbacks for this study. Collecting the data retrospectively is the main limitation. Relatively small sample size compared with the previous studies is a limitation as well.

\section{Conclusion}

In the light of our results, LVI, extracapsular extension and NLR are the predictive parameters of non-SLN positivity. Pre-surgical NLR is a useful diagnostic tool for predicting non-SLN metastasis. Further studies considering the NLR and non-SLN metastasis in different stages of breast cancer in cohort designs are awaited.

\section{Conflict of Interest: None}

\section{Source of Funding: None}

\section{References}

1. Veronesi U, Paganelli G, Viale G, Luini A, Zurrida S, Galimberti V, et al. Sentinel-lymph-node biopsy as a staging procedure in breast cancer: update of a randomised controlled study. Lancet Oncol.
2006;7(12):983-90.

2. Krag DN, Anderson SJ, Julian TB, Brown AM, Harlow SP, Costantino JP, et al. Sentinel-lymph-node resection compared with conventional axillary-lymph-node dissection in clinically nodenegative patients with breast cancer: overall survival findings from the NSABP B-32 randomised phase 3 trial. Lancet Oncol. 2010; 11(10):927-33.

3. Krag DN, Anderson SJ, Julian TB, Brown AM, Harlow SP, Ashikaga $T$, et al. Technical outcomes of sentinel-lymph-node resection and conventional axillary-lymph-node dissection in patients with clinically node-negative breast cancer: results from the NSABP B-32 randomised phase III trial. Lancet Oncol. 2007;8(10):881-8.

4. Noh H, Eomm M, Han A. Usefulness of pretreatment neutrophil to lymphocyte ratio in predicting disease-specific survival in breast cancer patients. J Breast Cancer 2013;16:55-9.

5. Azab B, Bhatt VR, Phookan J, Murukutla S, Kohn N, Terjanian T, et al. Usefulness of the neutrophil-to-lymphocyte ratio in predicting short- and long-term mortality in breast cancer patients. Ann Surg Oncol. 2012;19(1):217-24.

6. Laohawiriyakamol S, Mahattanobon S, Laohawiriyakamol S, Puttawibul P. The Pre-Treatment Neutrophil-Lymphocyte Ratio: a Useful Tool in Predicting Non-Sentinel Lymph Node Metastasis in Breast Cancer Cases. Asian Pac J Cancer Prev. 2017:18(2):557-62.

7. Gomez D, Farid S, Malik HZ, Young AL, Toogood GJ, Lodge JP, et al. Preoperative neutrophil-to-lymphocyte ratio as a prognostic predictor after curative resection for hepatocellular carcinoma. World J Surg. 2008;32(8):1757-62.

8. Ohno Y, Nakashima J, Ohori M, Gondo T, Hatano T, Tachibana M. Followup of neutrophil-to-lymphocyte ratio and recurrence of clear cell renal cell carcinoma. J Urol. 2012;187(2):411-7.

9. Koh CH, Bhoo-Pathy N, Ng KL, Jabir RS, Tan GH, See MH, et al. Utility of pre-treatment neutrophil lymphocyte ratio and platelet-lymphocyte ratio as prognostic factors in breast cancer. $\mathrm{Br}$ J Cancer. 2015;113(1):150-8.

10. Sachdev U, Murphy K, Derzie A, Shabnam J, Bleiweiss IJ, Brower $S$. Predictors of non-sentinel lymph node metastasis in breast cancer patients. Am J Surg 2002;183(3):213-7.

11. Chen JY, Chen JJ, Xue JY, Chen Y, Liu GY, Han QX, et al. Predicting Non-sentinel Lymph Node Metastasis in a Chinese Breast Cancer Population with 1-2 Positive Sentinel Nodes: Development and Assessment of a New Predictive Nomogram. World J Surg. 2015; 39(12):2919-27.

12. Koca B, Kuru B, Ozen N, Yoruker S, Bek Y. A breast cancer nomogram for prediction of non-sentinel node metastasis-validation of fourteen existing models. Asian Pac J Cancer Prev 2014;15(3): $1481-8$.

13. Mittendorf EA, Hunt KK, Boughey JC, Bassett R, Degnim AC, Harrell $R$, et al. Incorporation of sentinel lymph node metastasis size into a nomogram predicting nonsentinel lymph node involvement in breast cancer patients with a positive sentinel lymph node. Ann Surg. 2012 Jan;255(1):109-15. 